\title{
Neither Hitler nor Quisling: The Ragnarok Circle and Oppositional National Socialism in Norway
}

\author{
Terje Emberland
}

Center for Studies of the Holocaust and Religious Minorities

(HL-senteret), Oslo

terje.emberland@hlsenteret.no

\begin{abstract}
From 1935 to 1945 , Ragnarok was the most radical national socialist publication in Norway. The Ragnarok Circle regarded themselves as representatives of a genuine National Socialism, deeply rooted in Norwegian soil and intrinsically connected to specific virtues inherent in the ancient Norse race. This combination of Germanic racialism, neo-paganism, and the cult of the 'Norwegian tribe', led them to criticize not only all half-hearted imitators of National Socialism within Quisling's Nasjonal Samling, but also Hitler's Germany when its politics were deemed to be in violation of National Socialist principles. In Germany they sought ideological allies within the Deutsche Glaubensbewegung before the war, and the ss during the war. But their peculiar version of National Socialism eventually led to open conflict with Nazi Germany, first during the Finnish Winter War and then in 1943, when several members of the Ragnarok Circle planned active resistance to Quisling and the German occupation regime.
\end{abstract}

\section{Keywords}

Norway - National Socialism - Ragnarok - neo-paganism

The symbol of the Norwegian fascist party Nasjonal Samling [NS; National Unity], founded in 1933 under the leadership of Vidkun Quisling, was the socalled Olavs-cross, representing the warrior-king Saint Olav, who unified and christianized Norway. A few years back, I was rummaging through a shed next to an old cottage in the woods southeast of Oslo, when I found an old and moth 
eaten alternative flag for the Norwegian fascist party. It is the only one of its kind, and probably produced during the heated debates in 1934 concerning Nasjonal Samling's stance on religion. The Christian Olavs-cross had been replaced by the Norse Hagals-rune, the rune of life and death united - in this context symbolizing the racial and religious rebirth of the Norwegian tribe within the Germanic racial community. The cottage used to belong to Hans Solgaard Jacobsen, the editor of the journal Ragnarok.

From its debut in 1935 to its last issue in 1945, Ragnarok was the most radical national socialist publication in Norway. Before the occupation in 1940, the journal was politically independent and regarded it as its chief mission to criticize all half-hearted imitators of National Socialism within Nasjonal Samling. And yet, the rulers of the New Germany were also from time to time subjected to harsh criticism, if their politics were deemed to be in violation of National Socialist principles. During the war, Ragnarok was subjected to censorship, but in spite of this, the journal pursued a radical and uncompromising editorial line, which often brought Jacobsen and his followers into open conflict with both Nasjonal Samling and the German authorities.

The main reason for this oppositional outspokenness, was that the Ragnarok Circle regarded themselves as the representatives of a true and genuine National Socialism. Hence, they felt themselves in a position to criticize anyone who strayed from the straight and narrow. It is not difficult to understand why this unavoidably led to conflicts. Their ideological utopianism was doomed to collide head-on with the political realities in occupied Norway. However, there is more to this conflict than just an example of the difference between National Socialism as political utopianism, and National Socialism in power and as a fig-leaf of German imperialist politics. In order to understand precisely what lies at the core of this conflict, we have to take a closer look at the Ragnarok Circle and the ideological content of the allegedly pure National Socialism they propagated.

\section{Who were They?}

The journal Ragnarok was established as a direct result of tensions that had existed within Quisling's party, Nasjonal Samling, ever since its establishment in 1933. A conservative and Christian wing - including many of Quisling's closest associates - stood against a group of young, radical National Socialists. Fundamentally, the conflict concerned what kind of party Nasjonal Samling should be: An authoritarian Christian-nationalist movement directed against 
godless Bolshevism and the spiritual and cultural decay of modernity? Or, instead, the avant-garde of a National Socialist revolution, where racial thinking would constitute the guiding line for the reordering of society? ${ }^{1}$

Members of this radical wing were recruited mainly from former activists of the small Norwegian National Socialist Workers' Party, founded in 1932, who had then joined Nasjonal Samling in $1933 .{ }^{2}$ These where supplemented by older and more established men, who had their formative political impulses as students in Germany in the late 1920s. Amongst the latter was the undisputed leader of the radical wing, the social economist and shipbroker, Hans S. Jacobsen. Eventually the radicals lost the battle for control over the party. As a result, Jacobsen and some of his followers left Nasjonal Samling, while others decided to stay on to continue the battle from within. Soon thereafter Jacobsen established the monthly journal Ragnarok as a mouthpiece for the radical opposition both inside and outside the party.

Ragnarok managed to secure a thousand subscribers almost immediately. So, by usual calculation, it had no less than three times as many readers. ${ }^{3}$ This indicates that the numbers of radical National Socialists - at least by Norwegian standards - was fairly substantial. In 1937 the milieu was further boosted by the influx of more disillusioned former members of Nasjonal Samling, who left the party as a result of the conflict between Quisling and Johan B. Hjort, the head of the party's paramilitary wing, the Hird.

In spite of the backing from this broader milieu, the inner circle around Ragnarok consisted of no more than twenty individuals. Apart from a few older and more established men like Jacobsen, Albert Wiesener and Otto Engelschiøn, both former prominent members/organizers in Nasjonal Samling, the inner core consisted of several talented, but socially marginalized, young men, like the painter Stein Barth-Heyerdahl, a former activist of the Norwegian National Socialist Workers' Party; the writer Per Imerslund, formerly an SAactivist in Berlin and later a volunteer for Franco in the Spanish Civil War, and

1 Jacobsen to student Bruknapp on this conflict, Bestun, December 15 1971, PA Stein Barth Heyerdahl, PA Emberland, HL-centre. See also Dag Olav Bruknapp, 'Ideene splitter partiet,' in Fra idé til dom: Noen trekk fra utviklingen av Nasjonal Samling [From Idea to Judgement: Some Aspects of the Development of Nasjonal Samling], ed. Rolf Danielsen and Stein Ugelvik Larsen (Bergen: Universitetsforlaget, 1976), 9-47.

2 Terje Emberland, Religion og rase: Nyhedenskap og nazisme i Norge 1933-1945 [Religion and Race: Neo-paganism and Nazism in Norway 1933 - 1945] (Oslo: Humanist, 2003), 111-146. Terje Emberland and Bernt Rougthvedt, Det ariske idol: Forfatteren, eventyreren og nazisten Per Imerslund (Oslo: Aschehoug, 2004), 192-203.

3 The estimate is based on information from the University Library in Oslo, Riksarkivet, Oslo, L-sak Jacobsen. 
the well-known composer Geirr Tveitt, a passionate anti-Christian neo-paganist.

\section{Race}

The Ragnarok Circle may be called radical National Socialists, insofar as they wanted a fundamental and far-reaching change in the social, political, cultural, and religious makeup of society. And they believed that these fundamental changes could only be realized if one returned to the root. And to them, the root was race. Race and the struggle between races was the interpretative key by which one could understand history and society. In the ideal future society, culture, religion and as well as the socio-political organization of a society had to be moulded to fit the specific racial qualities of a people.

To them, race was a formative principle, which manifested itself in various degrees of perfection through the individuals belonging to a certain people. All races are seen as undergoing constant development. They can grow in purity and dignity, or they can degenerate. The task is, through cultural and political action, to reawaken the Germanic racial consciousness in the Norwegian people, and, by doing so unleash the dormant forces of the racial soul. This would eventually bring about a radical transformation of society. But their concept of race was not purely biologically defined. The main thing was that there are certain spiritual qualities attached to the different races. As Jacobsen writes: 'Race is a question of attitude, worldview, soul, just as much as physiology.4 And since racial purity is defined, not so much by strict biological criteria, as by rather fuzzy cultural and 'spiritual' concepts, this notion is obviously quite flexible and proved elastic enough to be reshaped to fit changing political circumstances.

\section{The Law of Mortal Danger}

This fluid and spiritualized concept of race is something which can also be observed in many other permutations of National Socialist ideology. What made the ideology of the Ragnarok Circle stand out as something original is the way they were able to combine this focus on the Germanic race with an ecstatic exaltation of Norwegians in particular.

4 Jacobsen in an article on Hans F.K. Günther, Ragnarok, no. 6-7 (September 1935): 169 . 
This combination was achieved by adopting the religious-evolutionary concepts developed by the Norwegian author Erling Winsnes. In his books Til en ukjendt gud (1919) [To an Unknown God] and Den neste stat (1925) [The Next State $]^{5}$ Winsnes turns Darwinist evolutionism into religious founding myth. In an aphoristic-philosophical style resembling Nietzsche's, the author proclaims a new gospel for the Nordic Man. This is based upon what he believed to be the eternal law governing all life; what he called 'the law of mortal danger': When the environment subjects us to mortal danger, this forces us to abandon our normal way of life and utilize and refine our inborn talents. By constantly being exposed to meagre and threatening living conditions, man is able to raise himself to new heights: 'The diamond is created under pressure, without pressure, no diamond. But without danger, no evolution, no animal, no man.' ${ }^{6}$

Winsens goes on to explain how the 'law of mortal danger' has created the different human races. In prehistory, the primal herd of humans was faced with a choice when the glacial ice withdrew. Some decided to go south to look for a more pleasing environment, others decided to stay where they were. These became the African and the Asiatic races. The forefather of Nordic Man, on the other hand, made a different choice: 'Let us go to the north', he said. 'Let us learn to fight against the dragons who are the enemies of God and Life. Let us increase our arms' strength and re-conquer God's kingdom on Earth.7 By doing so, he and his followers exposed themselves to the greatest danger, Winsnes claims, and became taller, stronger and brighter than any other race.

However, this 'law of mortal danger' does not only account for the differences between the races. It also applies within each separate race. Consequently Winsnes establishes a hierarchy within the Germanic race, where Norwegians not surprisingly - represented utmost pinnacle of racial evolution, since 'those who live under the greatest danger, educates themselves and their race to take up the future staff of dominion. ${ }^{8}$ As the living conditions in Norway are amongst the most demanding on earth, Norwegians have been forced to refine and develop their racial qualities like no other members of the Germanic race. And they have kept the racial wisdom virtually intact in their myths and in their blood. Other peoples like the Germans and Danes, on the other hand, have degenerated through the ages. By living in a fertile and easily cultivated,

5 Erling Winsnes, Til en ukjendt gud: slegternes vekst, blomstring og undergang [To an Unknown God: The Growth, Flowering and Decline of Generations] (Kristiania: Cammermeyer, 1919);

Erling Winsnes, Den neste stat (Oslo: Fabritius \& Sønners Forlag, 1925).

6 Winsnes, Den neste stat, 33 .

7 Ibid., 16.

8 Ibid., 48. 
but sadly monotonous landscape, they have developed into rigid bureaucrats and narrow-minded materialists.

Winsnes's evolutionary philosophy was eagerly taken up by the Ragnarok Circle. One important reason for this was that it could justify a greater national variation within the family of national socialisms. Even though the core concepts held true for all members of the Germanic race - so the argument went the specific political form it took in each country was dependent on the cultural and racial characteristics of the that specific tribe or people. Consequently, the German variety of National Socialism was regarded as fruit of the German soil, and was formed by the racial peculiarities of the German people. So, too, should Norwegian National Socialism be rooted in the Norwegian soil, and reflect the racial qualities of the Norwegians.

Taken one step further, this could also be used as a ground for criticism of aspects of German National Socialism which did not meet the approval of the Ragnarok Circle. For example, they argued, it was too militaristic and conformist to fit the independent, Viking spirit of Norwegians. In fact, Stein BarthHeyerdahl argues already in 1934, this spirit constituted the true core of National Socialism. Since it is 'primarily Nordic and its philosophy Old Norse, it is more Norwegian than German.'

This interpretation of National Socialism is also apparent in Hans S. Jacobsen's critique of Italian Fascism. To him Fascism was the manifestation of Levantine universalism - 'the spirit of Judea and Rome', as he puts it. In foreign policy, this universalistic attitude expressed itself in Italian imperialist policy in Africa, and the attempt to export fascist ideology to other European nations through the organisation for 'universal fascism' with its seat in Switzerland. In sharp contrast to this imperial arrogance, National Socialism, claimed Jacobsen, is characterized by its focus on human diversity and the substantial side of existence, of the holy right of healthy, natural, organic life, and the differences between peoples. ${ }^{\prime 10}$

\section{Religion}

Jacobsen and his circle also employed their radical racialism and adoption of Winsnes's philosophy in order to attack Christianity. The Christian religion was the prime agent of racially alien influences in Norwegian society. For a thousand years, it had had dulled the Norwegian racial spirit and turned the people

$9 \quad$ Nasjonalsocialisten, no. 5 (May 1934).

$10 \quad$ Hans S. Jacobsen, 'Nasjonalsocialisme og fascisme,' Ragnarok, no. 6-7 (September 1935):141. 
into the slaves of foreign powers. A racial awakening therefore made a return to Norse religion, although in a modernized form, a real necessity. And this was not an issue of marginal importance. The question of religion played a vital part in their propaganda. In fact, articles dealing with religious issues occupied a substantial part of the journal throughout its existence. In many ways their anti-Christian neo-paganism became the single most important ideological element, which set them apart from the more 'moderate' trends of Norwegian fascism. Also during the war, when censorship limited the possibility of open criticism, attacks on Christianity were often used as a cover for attacks against Nasjonal Samling and the German occupation regime.

This is not to say that the Ragnarok Circle did not take their neo-paganism seriously. In many respects their religious ideas were instrumental in forming their identity. To many, the fight against Christianity and for a modernized Norse religion was the single most important issue.

As with all other important issues, their thoughts on religion were shaped by their radical racialism. To them, race not only defined the outer form of religion - its rituals, myths and customs - but race and racial belonging also constituted the true object of religion. Race is seen as lying at the innermost core of all religion and representing its deepest truth.

In short, the Ragnarok Circle's religious belief was a kind of 'naturalistic pantheism', where 'God' was a used in a very abstract way, as a synonym for the immanent 'divine racial law' governing nature, history, and human life. In many ways this law was identical to the 'law of mortal danger' developed by Winsnes. Salvation is regarded as the work of Man himself. It is achieved by realizing ones racial potential and in doing so live in harmony with the 'divine law'. Incidentally, it is interesting to note how their violent rejection of Christian otherworldliness, its concept of sin, and the belief in miracles mirrors the critique launched at Christianity by the National Socialists' own political enemies of the left.

Even though the symbols and myths of Old Norse religion were frequently used in their writings, it is a misconception to think that the Ragnarok Circle wanted to reinstate the former Norse cult of Thor and Odin. Rather, they offered a metaphorical interpretation of Norse religion, where myths and imagery where thought to express deep biological and racial truths. Behind the outer trappings of the old religion of the Vikings, lies the perennial wisdom of life.

How did then this perennial wisdom survive through the dark ages of Christian rule in the Germanic world? How was it transmitted? Even though it is quite vaguely expressed, it seems that they thought it to be contained within the blood - not to be understood in a strict biological sense, but rather as a metaphor for a kind of the collective subconscious shared by the members of 
the Germanic race. This in turn led to the idea that certain individuals where endowed with an extraordinary ability to tap into this collective racial subconsciousness by 'listening to the voice of the blood'.

Obviously, such charismatic gifts were the prerogative of a select few - the racial prophets. The validity of Norse religion could, however, be verified not only by this kind of mystical introspection, but also by quite straightforward and rational means. For - unlike the obsolete and refuted concepts of Christianity the inner truths of Norse religion were entirety in accordance with the results of modern science. The perennial wisdom, which the Old Norse religion expresses in mytho-poetic language, is today presented in concrete and objective terms by modern science. Hence, their neo-pagan religion was to them rational, forwardlooking, and in accordance with the needs of modern man.

\section{Pan-Germanism}

If one regards racial belonging as the defining principle, this also will shape the perception of the national state. Within the Ragnarok Circle the idea of the spiritual and biological kinship of all Germanic peoples led to the idea of a close political union of all Germanic nations. To them, unlike the nationalists within Nasjonal Samling, the Norwegian nation state was not given by nature, but had been formed by specific historical circumstances. All states are manmade and historically dependent. Race, however, is a fixed and absolute fact.

Although the Norwegian national state was a result of historical circumstances, this did not, however, imply that the Norwegian people were an arbitrary product of such circumstances. The feeling of kinship amongst Norwegians did not stem from a shared identification with the nation state, but from an inherent tribal feeling, rooted in the shared racial characteristics which had been formed and refined by a harsh natural environment. Hence, this kinship between all Norwegians had existed long before the creation of the state of Norway.

To the Ragnarok Circle the future Pan-Germania was not identical to the German Reich. Although Germany was the leading nation, this did not imply that it could force unification upon the smaller Germanic nations by means of imperialist expansion or violent occupational regimes. The anti-universalistic ideals of National Socialism meant that one had to respect the freedom and sovereignty of each Germanic tribe. The racial awakening had to happen 'within the framework of each people', as Jacobsen put it."1

11 Jacobsen, 'Nasjonalsocialisme og fascisme,' 141. 
After the German occupation of Norway, the Ragnarok Circle reacted strongly against what they deemed an imperialistic use of the pan-German ideals. 'We have always wanted constructive cooperation and a pan-Germanic union,' Hans S. Jacobsen writes. 'But if this implies that smaller Germanic states are to be branded second-rate, just because they do not have as many inhabitants, we are on the wrong track. This kind of international majority rule is hardly in line with Nordic principles and will not be a blessing to either the bigger, or the smaller states. It is the racial question which should decide. And according to this view, there is no reason why a smaller people should not govern a larger.'12

\section{The Ragnarok Circle and the Deutsche Glaubensbewegung}

Many of the views held by the Ragnarok Circle where also propagated - at least at a rhetorical level - by certain National Socialist and völkisch milieus in Germany. And it is a particular trait of the Norwegian group from the beginning it cultivated extensive contacts to different organisations and high-ranking circles in Nazi-Germany - where their peculiar Norwegian brand of radical neo-pagan National Socialism found - or was perceived to find - resonance.

Attitudes towards Christianity were the focal point in the conflict in 1935 and 1936 between the leadership of Nasjonal Samling and the Ragnarok Circle. It was therefore only natural that one of the first contacts made in Germany was with the Deutsche Glaubensbewegung [The German Faith Movement], and with its leader, Wilhelm Hauer, who also propagated a racial religion based on modernized paganism as a replacement for Christianity. In 1935 Geirr Tveitt visited Hauer in Tübingen, which resulted in a lasting friendship. The Norwegian composer also became introduced to other prominent persons in the movement, like the administrative leader Paul Zapp and the racial ideologue and author Hans F.K. Günther. ${ }^{13}$ The cooperation between the Ragnarok milieu and the Deutsche Glaubensbewegung resulted in nomination of Jacobsen to the editorial committee of the periodical Deutscher Glaube in 1936 and in attempts to form an Norwegian chapter. The contact with Hauer and his followers continued all through the inter-war years. ${ }^{14}$ Tveitt joined the editorial

\footnotetext{
12 Ibid.

13 From June 1941 to July 1942 Zapp was leader of Sonderkommandos 11a of the Einsatzgruppe D, responsible for mass executions of Ukrainian civilians.

14 Jacobsen to Hauer, Moss, June 6 1936, Bundesarchiv, Koblenz, Hauer N1131, 65, 49.
} 
staff of Ragnarok, where he became one of the most active supporters of Hauer and his movement. In 1936 he invited the German professor on a lecture tour in Norway. The plan was most likely to launch a Norwegian section of the Deutsche Glaubensbewegung during Hauer's visit.

However, around 1935-36 the political climate in Germany changed. Hitler made a provisional peace with the Churches, and there was no longer any need for the regime to use the neo-pagans as a veiled threat against Christian dominance. All public activities of the Deutsche Glaubensbewegung were banned in 1936, and Hauer himself was denied permission to leave the country - mainly to avoid creating anxiety and hostility towards the regime in the foreign press. Soon afterwards, Hauer left his movement, and, once taken over by loyal Nazi party activists, it was gradually disbanded and absorbed into different sections of the NSDAP and the Nazi state.

This religious Gleichshaltung was met with great disappointment by the Ragnarok Circle. Prior to this, the tone had been one of millenarian optimism: inspired by the German example, the racial awakening of the Norwegian people had been seen as imminent. This would inevitably lead to a religious reformation, where the majority of population world cast off the yoke of Christianity, and return to their religious roots. But now, with the revolutionary forces of German National Socialism being curbed the policy of Gleichshaltung, there was little optimism for a neo-pagan reformation any time soon. The only hope was that a close-knit elite of racially conscious neo-pagans would keep the flame alive.

\section{The Ragnarok Circle and the ss}

Jacobsen voiced his concern in a conversation with Himmler during the annual conference of the Nordische Gesellschaft in $1937 .{ }^{15}$ And the Reichsführer ss, himself an ardent anti-Christian, must have been very understanding, since this meeting marked a shift in Ragnarok Circle's German networks. When it gradually dawned on the Norwegians that Hauer and his neo-pagans could no longer function as an efficient ally, their focus gravitated more towards

15 Jacobsen to Hauer, Moss, December 12, 1937, Bundesarchiv, Koblenz, Hauer N1131, 65, 45. Himmler was at that time already well informed on the conflicts within the Norwegian NS-movement through his meeting with Johan B. Hjort: '[19.30:] Besuch bei Graf von der Goltz, Wannsee. Besprechung mit Herrn Hjord[sic], Norwegen.' Himmler's Diensttagebuch, Tagebuch RF-SS 14.juni 1937, RGVA, Moscow, former 'Osobyj archiv', fond 1372k, opis 5, delo 218, list 429. Thanks to Dr. Matthew Kott for this information. 
Himmler and his organisation, especially after the German occupation of Norway.

In the summer of 1940 Jacobsen travelled to Germany on behalf of the Ragnarok Circle and other prominent pro-German, anti-Quisling Norwegians who had received disturbing reports indicating that Hitler had decided to opt for a government led by Quisling. In Berlin he was received by Himmler himself. Himmler was no supporter of Quisling, but was compelled to inform Jacobsen that Hitler's decision was final. ${ }^{16}$ However, later that year he wrote to Jacobsen, assuring him the Ragnarok Circle would soon be given the opportunity to fight for their ideas within the framework of the ss, since it had been decided to establish a local equivalent to the Allgemeine-ss in Norway - Norges ss, later renamed Germanske ss Norge (GSSN). ${ }^{17}$

According to Jacobsen's view, the ss was an exponent of 'aristocratic socialism', and drew together the supreme elite of committed idealists within the Germanic countries. It 'struggled for full equality and against any degrading or suppression of the racially kindred Norwegian people', as he puts it. ${ }^{18}$ Consequently, the GSSN, and the ss in general, seemed to strive for exactly the same goals as the Ragnarok Circle, and could therefore in the latter's view be of use in their oppositional struggle against Quisling and Terboven. It is thus no wonder that they grabbed at the offer made by Himmler. Jacobsen became editor of Germaneren, the house organ of the GSSN, and Per Imerslund became one of its most prominent contributors.

Today it may seem incredibly naïve for them to have thought that it would be possible to make use of the ss to further their own goals. But if we consider it from the perspective of Jacobsen and the Ragnarok Circle, it becomes more understandable. They really believed that any true National Socialist had to feel committed to racial solidarity, and therefore respect the autonomy and individuality of each of the Germanic peoples. From this perspective, any misconduct or abuse of power by the German occupation regime must be regarded as a result of a lack of knowledge of, or a disregard for the true principles of National Socialism.

The harmony did not last long, however. From the side of the ss, a change of heart in this milieu was noted in May 1943. In a report written by the SD rapporteur Fritz Vollberg he warns the ss Ahnerebe from inviting people from the Ragnarok Circle to a conference in Hannover. There is no reason to doubt their

16 Note to the police in Moss from Otto Sverdrup Engelschiøn, January 1 1946, Riksarkivet, Oslo, box 2, L-sak Jacobsen.

17 Himmler to Jacobsen, Berlin, January 1 1941, transcript, Riksarkivet, Oslo, L-sak Jacobsen.

18 Note from Jacobsen on the GSSN, undated, Riksarkivet, Oslo, L-sak Jacobsen, box 2. 
pan-Germanic idealism, Vollberg writes, but this has of lately taken on a form which identifies Norwegians as the only true and genuine Germanic people. It is therefore rather a form of 'Norse nationalism. ${ }^{19}$ The only mistake Vollberg makes in this analysis it to think that this was a recent ideological development. This oppositional and chauvinistic interpretation of Nordicism and panGermanism, inspired by Winsnes, was there from the very start, but became more pronounced when it became apparent to the Ragnarok milieu that the ss ultimately served German imperialist goals.

\section{The Finish Winter War}

To backtrack a little, the ideological clash between the Ragnarok Circle and Nazi Germany peaked for the first time with the signing of Molotov-Ribbentrop Pact in August 1939 and the following Winter War in Finland. The Ragnarok Circle gave its unconditional support to the Finns' cause. The writer Per Imerslund himself volunteered and many others amongst the radicals followed his example.

This also led to sharp criticism of the foreign policy of Hitler's Germany. In 1940 Otto Engelschiøn took over as editor of Ragnarok. In his first editorial, commenting on the Molotov-Ribbentrop Pact, he asks if 'the Nordic idea' was only a hobby which could be discarded as soon as the interests of Germany were threatened. He went on to lament how the plague of universalistic imperialism now seemed to have infested even Hitler's New Germany: 'We prefer the most inadequate Norwegian democracy to life as a protectorate, whoever the protector. Norway is not, and never shall be any other countries "sphere of interest". The masters in Kremlin, Berlin and London should take notice of this, 'he concludes. ${ }^{20}$ This fierce attack from what were regarded as loyal supporters of German Nazism was noted with much concern by the Foreign Office in Berlin. ${ }^{21}$ Even so, the Ragnarok circle did not discard their pan-Germanism. The fact that Germany now seemed to have abandoned its ideals only

19 Hans Schwalm, 'Vermerk, ss-Hauptsturmführer Schwalm, Ahnenerbe i Oslo. Betr:: Tagung in Hannover am 13., 14. und 15. Mai 1943. Bezug: Unterredung mit ss-O'Stuf. Dr. Volberg am 6.4.1943.' NS 21/805, Bundesarchiv, Berlin, copy, Riksarkivet, Oslo, PA Ingebriktsen.

20 Ragnarok, no. 1 (January 1940).

21 Report to Auswärtiges Amt January 1940, AA, Pol.Arch, Berlin doc. no. P VI 428, 'Gez. II. Presse u. Propagandawesen Allgemein 1939-40.' Immediately after the German occupation of Norway, this issue of Ragnarok was confiscated. 
demanded an ideological adjustment. It was now up to the smaller NorthGermanic countries to take the lead in the process of racial unification.

The Winter War was a particularly important point of contact between the Ragnarok Circle and other fascists on the European periphery. Many members of these peripheral fascist movements participated as volunteers on the Finnish side. To them, this was the Great Ideological War - a North European equivalent to the Spanish Civil War. The Ragnarok Circle was deeply engaged in the Finnish cause, and some even volunteered to fight. So, too, did the Latvian Pèrkonkrusts leader Gustavs Celminiš. At that time, all these various fascist radicals shared the disillusionment over Hitler's treacherous pact with Stalin. It is not unlikely that this spurred their efforts in establishing international organisational cooperation that would be independent of the control of both Hitler's Germany and Mussolini's Italy.

\section{Resistance}

In the first year of German occupation in Norway, the Ragnarok Circle was engaged in wide-ranging intrigues to prevent Quisling from gaining power. After 25 September 1940, when Reichskommissar Terboven banned all parties except Nasjonal Samling, the battle seemed lost. Now they had to decide what strategy to pursue. The two editors, Jacobsen and Engelschiøn, chose the completely opposite paths. Jacobsen became member of Nasjonal Samling and was appointed regional commissioner in Østfold district. By contrast, Engelschiøn opted for active resistance and later became head of intelligence services in a central section of the Norwegian resistance movement. The younger activists chose a middle position, where they remained outside Nasjonal Samling, but tried to gain influence through activities initiated by the ruling party and the German authorities.

Their discontent was, however, greatly dampened when Germany attacked the Soviet Union in the summer of 1941. Now it looked like Hitler was finally going to honour the principles of National Socialism. The recruitment of Germanic volunteers to the Waffen-ss especially was interpreted as sign of a revitalization of the pan-Germanic ideals. As already mentioned, this harmonious relationship between the Ragnarok Circle and the ss did not last long. It soon became apparent that the recruitment of Norwegians to the Waffen-ss also served German imperialist intentions. At the same time, their embitterment over Terboven's heavy-handed rule and Quisling's puppet government grew by the day.

In late summer 1943 they had enough, and decided to engage in active resistance. The main initiator was Per Imerslund, who believed that it was possible 
to form an alliance between disillusioned comrades within the Waffen-ss and people within the resistance movement. This alliance was to be organised in small cells, and would at a given time start guerrilla warfare against the occupants and Quisling's corrupt regime. The group even plotted to kidnap Quisling and execute him for his crimes against the Norwegian national will. Although Imerslund began recruiting people for this conspiracy, his plans never reached fruition, due to his sudden death. ${ }^{22}$

In retrospect, the whole plot seems to have been complete madness. Yet in the Ragnarok Circle's mode of thinking, it was quite natural. According to the philosophy of Winsnes, the leadership of the future racial state was to comprise people who in their own life had exposed themselves to 'the law of mortal danger', and hence had become the new racial nobility. To them it was beyond doubt that it was the youthful nobility from both the Waffen-ss and the resistance movement who had to join together, drive the Germans out of the country and lead the fight against the anticipated Russian invasion.

\section{Conclusions}

The story of the Ragnarok Circle is the story of the attempt to establish an autonomous and essentially Norwegian National Socialism. It was an attempt to reconcile and combine racial ideology and pan-Germanism with the veneration of what was regarded as specifically Norwegian. It is also the story of how this project time and time again led to clashes with Nazi Germany. The original ideological element, represented by the philosophy of Winsnes, was there from the start. However, it became gradually more accentuated when the political realities under German occupation came into increasingly sharp conflict with their maximalist National Socialist utopianism.

These conflicts, which eventually led them into active resistance, did not make them renounce their ideological convictions, however. As they perceived it, Norwegian National Socialism was not dependent upon Hitler's Germany. The step taken, from active participation in Waffen-ss and cooperation with the Quisling regime and German occupation authorities, to active resistance must therefore be considered as basically a change of strategy. The goal, however, remained unchanged, namely, the realization of a racially-based new social order, both in Norway and in the entire Germanic world.

The story of the Ragnarok Circle shows us that there existed a variety of ideological differences in respect to the interpretation of National Socialism, 
nordicist racial ideology and pan-Germanism. And that these differences also created conflicts between the ss and groups which were perceived as its most loyal supporters in the occupied countries. Moreover, this story is not unique. The ideology of the Ragnarok Circle shows many similarities with similar fascist and national socialist movements, groups and milieus in what we might name the 'European periphery'. Here we find people who, by employing völkisch, religious and social Darwinist ideas, modified the concept of National Socialism to fit their particular national culture and history. And for many of these groups this led at one time or another to conflicts with Nazi Germany. It is time to start talking about various 'national socialisms' rather than one 'National Socialism'. 